\title{
炭酸ランタン服用患者の胃粘膜へのランタン沈着の検討
}

\author{
浪江 智1 浜辺 定徳 ${ }^{1}$ 川冨 正治1 川冨 ${ }^{1}$ 弘 $^{1}$ \\ 小田英俊 ${ }^{2}$ 中沢将之西野友哉4 \\ ${ }^{1}$ 川冨内科医院 ${ }^{2}$ 佐世保中央病院内科 3 佐世保市立総合病院内科 \\ ${ }^{4}$ 長崎大学附属病院第 2 内科
}

\section{キーワード：炭酸ランタン，腹部 CT, 胃内視鏡検查，組織沈着}

\section{〈要旨〉}

炭酸ランタンを服用中の 70 例の血液透析患者の腹部単純 CT における胃の high density area (HDA) について検討 した. 70 例に 173 回のCT 検査を行ったが, そのうち明らかな HDA を認めたものは 42 例 (60\%) に計 67 回 (39\%) であった. HDA を認めた群（42 例）はHDA を認めない群（28 例）と比較して, 炭酸ランタンの服用期間が有意に 長かった。 また, 服用期間が長いほどHDA の程度が有意に強かった。胃内視鏡検査を施行した 4 例の内視鏡所見 は胃粘膜の白色肥厚が特徵的にみられ, 組織所見は胃粘膜固有層に沈着物を認め, マクロファージの浸潤と貪食像 を認めた。胃組織中のランタン定量分析では, ランタンの存在が確認された。炭酸ランタンを服用中止して 8 か月 後に経過をみた 2 例の腹部 CT では, HDA は残存し， 1 例の胃内視鏡所見では胃粘膜の白色肥厚が残存した．炭酸 ランタンが胃粘膜に与える影響について, 注意深い観察が必要であると考えられた.

\section{Investigation of deposition of lanthanum on gastric mucosa in hemodial- ysis patients with lanthanum therapy}

Satoru Namie ${ }^{1}$, Sadanori Hamabe ${ }^{1}$, Masaharu Kawatomi ${ }^{1}$, Masahiro Kawatomi ${ }^{1}$, Hidetoshi Oda ${ }^{2}$, Masayuki Nakazawa ${ }^{3}$, Tomoya Nishino ${ }^{4}$

${ }^{1}$ Kawatomi Medical Clinic, ${ }^{2}$ Sasebo Chuo Hospital, ${ }^{3}$ Sasebo City General Hospital, ${ }^{4}$ Second Department of Internal Medicine, Nagasaki University

Key words : lanthanum carbonate, abdominal CT, gastric endoscopy, tissue deposition

$\langle$ Abstract〉

We investigated high-density area (HDA) in the stomach on abdominal CT in hemodialysis patients with lanthanum therapy. We examined abdominal CT results of 173 examinations in 70 patients during the therapy; 67 of these 173 examinations (39\%) in 42 patients (60\%) showed HDA in the stomach. The duration of lanthanum therapy in patients with an HDA was significantly longer than that in patients without it $(p<0.01)$. Furthermore, the duration of lanthanum therapy was positively correlated with the grade of HDA $(p<0.0001)$. We performed gastric endoscopy in 4 cases. It showed white thickening of the gastric mucosa along the fold. Pathological findings of biopsy showed the tissue deposition of lanthanum with macrophages. The presence of lanthanum in the gastric mucosa was confirmed by inductively coupled plasma mass spectrometry (ICP-MS). Eight months after discontinuation of lanthanum therapy, two cases were examined by CT and one of them also underwent gastric endoscopy. The HDA or white thickening of the gastric mucosa persisted in the findings for these procedures. Our findings suggest that further investigations of the influence of lanthanum carbonate on gastric mucosa are needed. 


\section{緒 言}

炭酸ランタンは高リン血症の治療薬として, 慢性腎 臓病（chronic kidney disease：CKD）の患者に広く用 いられている，炭酸ランタンは有効であり，忍容性が 高く，重篤な副作用は少ない ${ }^{1,2)}$. 副作用としては吐き 気や嘔吐といった消化器症状がみられると報告されて いる ${ }^{3)}$ ，炭酸ランタンの薬物動態であるが，炭酸ラン タンは腸管から血中への吸収率は $0.00127 \%$ と非常に 低いと報告されている4)。吸収されたランタンは骨と 肝臟に集簇し, 胆汁中に排泄される ${ }^{5 \sim 7)}$ 。腸管からの 吸収率が低いため骨や肝臟のランタン濃度は高くなら ず，直接的な毒性はないと報告されている ${ }^{8,9)}$. 一方で 炭酸ランタンを服用した血液透析患者の剖検例で, 腸 間膜リンパ節にランタンの沈着を認めたと報告され た ${ }^{10)}$ 。しかし，胃粘膜にランタンが沈着したという報 告はない。

また, ランタンは X 線透過性がないため, 腹部 X 線 検查や，腹部 CT 検查では検查の妨げになることが知 られている ${ }^{11,12)}$ 。当施設では血液透析患者に腹部 CT 検查を行う際, 1 週間前から炭酸ランタンを休薬して, 炭酸ランタンが消化管内に残存していない条件で撮影 している. しかし，そのCT 画像に扔いて，胃壁に層 状の high density area（HDA）が認められた。 そこ で, 形態学的検査と成分分析を行い, 炭酸ランタン服 用歴との関連性を検討した.

\section{I 、研究目的と研究デザイン}

CT 画像に打ける胃の HDA と炭酸ランタンの服用 に関連があるかどうかを検討するため，後ろ向き観察 研究 (症例研究) を行った.

\section{II. 方 法}

1. 2010 年 1 月から 2014 年 5 月の期間で炭酸ランタン を8か月以上服用した血液透析患者 70 例を対象者に行 われた。

\section{2. 胃の HDA の評価方法}

炭酸ランタン服用中に撮影した腹部単純 CT 画像か ら，胃の high density の程度を淡い，明暸，濃いの 3 段階に分け, 範囲の広がりを加味して G0 から G6 に分 類した(表 1)。G2 以上を明らかな HDA とした。典型 的な CT 画像を図 1 に示す. 各回の CT 画像に扔いて HDA の判定は 1 名の医師が行った.

\section{表 1 胃の HDA の判定基準}

$\begin{array}{ll}\text { G0 } & \text { HDA なし } \\ \text { G1 } & \text { 一部に淡くHDA を認める } \\ \text { G2 } & \text { 全体的に淡くHDA を認め, 一部に明瞭な HDA を認める } \\ \text { G3 } & \text { 明瞭な HDA を多く認め, 他の部位に淡くHDA を認める } \\ \text { G4 } & \text { 全体的に明瞭な HDA を認める } \\ \text { G5 } & \text { 全体的に明瞭な HDA を認め,一部に濃くHDA を認める } \\ \text { G6 } & \text { 全体的に濃くHDA を認める }\end{array}$

\section{3. 炭酸ランタンの服用状況と HDA の関係}

各症例の最後の CT 検査で胃の HDA の有無により 2 群に分けて, 炭酸ランタンの服用期間, 総服用量, 併用薬との関連を検討した。また，炭酸ランタンの服 用期間と胃の HDA の分類について関連性を検討し た．統計解析のソフトウェアは statcel3 用いて, 有 意差検定は $t$ 検定抢よびカイ二乗検定を行った.

\section{4. 形態学的検討}

4 例において炭酸ランタンを 3 日間休薬した後に胃 内視鏡検查を行い，肉眼的観察を行うと同時に，病理 組織検查を行った．組織診断は通常の光学顕微鏡的観 察と, 連続切片で AE1/AE3, CD68 の免疫染色, およ び電子顕微鏡による観察を行った。

\section{5. 胃組織中のランタンの定量分析}

ICP（inductively coupled plasma）質量分析法を用 いて内視鏡検查時に採取した胃組織中のランタンの定 量分析を行った。

\section{6. 経時的観察}

炭酸ランタン中止後 8 か月を経過した 2 例で腹部 CT 所見と 1 例の内視鏡所見を検討した.

\section{7. 対象者への説明と同意}

検査結果はすべて開示され, 研究については個人情 報保護を厳重に守り，目的以外に使用しないことを説 明し同意を得た。

\section{III. 結 果}

\section{1. 炭酸ランタン服用状況と胃の HDA の関連}

観察期間中に 70 例の患者に合計 173 回の CT 検查が 行われた．撮影回数は症例により異なり，1回から 5 回であり，平均は 2.5 回（中央值 2 回）であった。複 数回撮影した症例ではより後の CT 検査の HDA の程 度が強く, 服用中に HDA の程度が軽減した症例はな かった. 173 回の CT 画像の HDA を解析すると G2 以 上に判定されたものは 67 回 (39\%) であった (図 2a). 各症例の最後の CT 検查では 70 例中 42 例 $(60 \%) に$ G2 以上の HDA を認めた（図 2b).HDA の有無によ り 2 群に分けて炭酸ランタンの服用期間, 総服用量, 

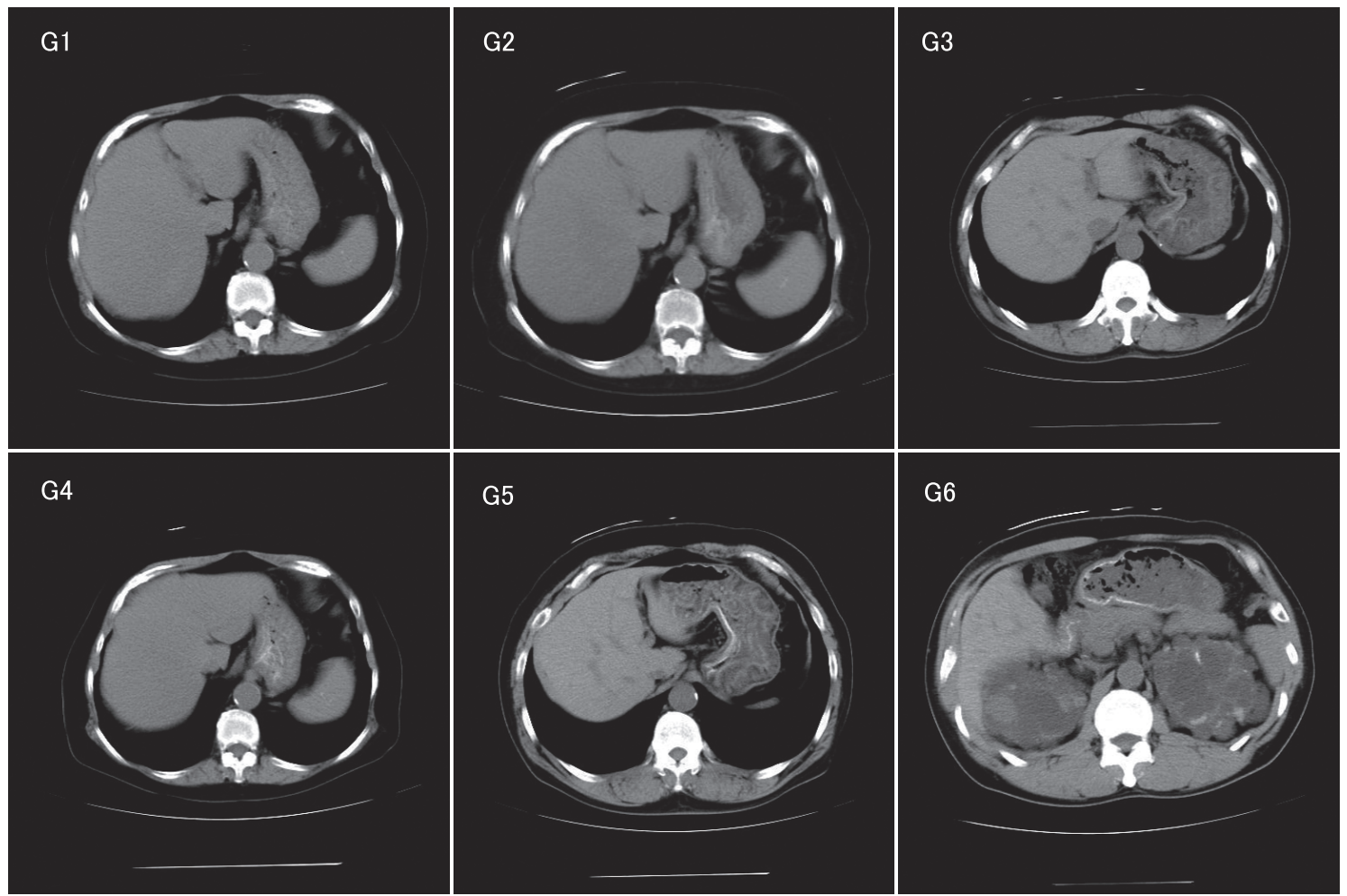

図 1 胃の HDA の判定基準

G1，G2，G4 は同一症例であり，炭酸ランタンの服用期間はそれぞれ 1 年 5 か月， 3 年 6 か月，4 年 1 か月であっ た。 また G3，G5 は同一症例であり，服用期間はそれぞれ 10 か月と 3 年 10 か月であった. G6 の服用期間は 4 年 1 か月であった.

a) 総撮影件数 $(n=173)$

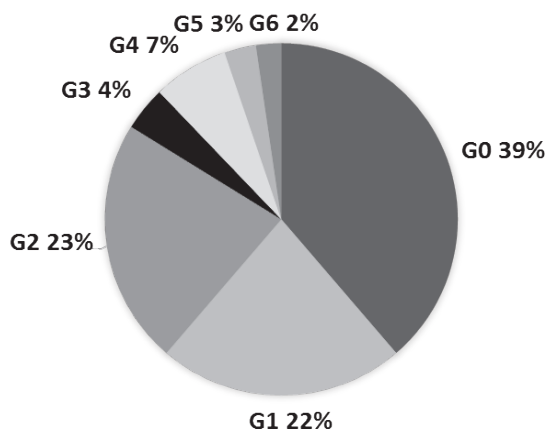

HDAあり $39 \%$ b) 各症例の最終撮影時 $(n=70)$

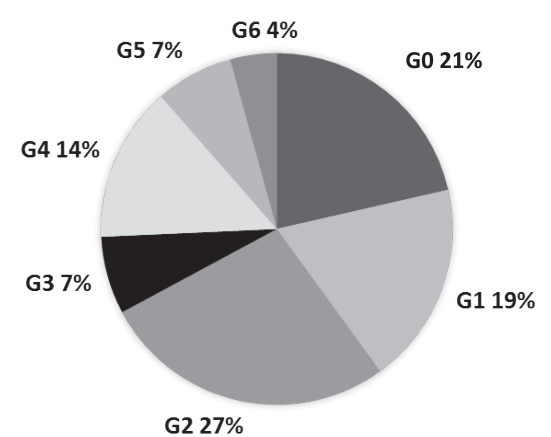

HDAあり $60 \%$

図 2 胃の HDA の出現頻度と程度

a ) 総撮影件数 173 回のうち $\mathrm{G} 2$ 以上 (HDA あり) は $39 \%$ であった。

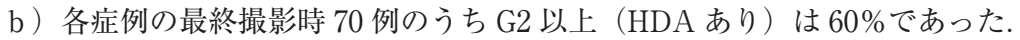

併用薬との関連を検討したところ, 炭酸ランタンの総 服用量では差はなかったが，服用期間は HDA のある 群で有意に長かった（表 2, 図 3)。また，制酸郕（プ ロトンポンプ阻害薬 $+\mathrm{H}_{2}$ ブロッカー) や粘膜保護剤と HDAの関連は認めなかった（表 2).

次いで，炭酸ランタンの服用期間と胃の HDA の程 度との関連を検討した．図 1 で例示した G1，G2，G4 は同一症例であり，炭酸ランタンの服用期間はそれぞ
れ 1 年 5 か月, 3 年 6 か月, 4 年 1 か月であった。ま た，G3，G5 は同一症例であり，服用期間はそれぞれ 10 か月と 3 年 10 か月であった. 2 例とも服用期間が長 くなると HDAの程度が強くなっていた. CT 撮影件数 全体では 1 年以内服用者の CT では G2 以上は $10 \%$ 以 下だったが，4 年以上服用者の CT では $80 \%$ 近くに増 加し, 服用期間が長いほど, HDA の程度が有意に強 かった（p<0.0001）（図 4). 
表 2 対象と服薬状況

\begin{tabular}{|c|c|c|c|c|}
\hline & 全体 & HDA なし & HDA あり & $\mathrm{P}$ 值 \\
\hline 例数（\%） & $70(100)$ & $28(40)$ & $42(60)$ & \\
\hline 男女比 & $34: 36$ & $15: 13$ & $19: 23$ & 0.494 \\
\hline 年齢（歳） & $61.6 \pm 11.4$ & $59.4 \pm 12.9$ & $63.1 \pm 10.1$ & 0.182 \\
\hline 透析歴（年） & $14.8 \pm 6.8$ & $14.1 \pm 6.2$ & $15.3 \pm 7.2$ & 0.487 \\
\hline $\mathrm{La}$ 服用量（mg/日） & $1,307 \pm 519$ & $1,330 \pm 509$ & $1,291 \pm 532$ & 0.762 \\
\hline La 服用期間（年） & $3.11 \pm 1.12$ & $2.61 \pm 1.19$ & $3.45 \pm 1.05$ & 0.003 \\
\hline La 総服用量（g） & $4,615 \pm 3,128$ & $3,672 \pm 2,583$ & $4,508 \pm 2,403$ & 0.171 \\
\hline 制酸薬（\%） & $51 / 70 \quad(72.9)$ & $19 / 28(67.9)$ & $32 / 42(76.2)$ & 0.442 \\
\hline 粘膜保護薬（\%） & $33 / 70 \quad(47.1)$ & $13 / 28(46.4)$ & $20 / 42(47.6)$ & 0.922 \\
\hline
\end{tabular}

a) 炭酸ランタン服用期間

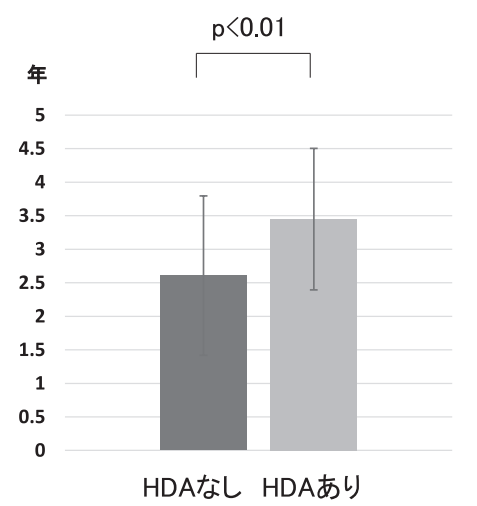

b) 炭酸ランタン総服用量

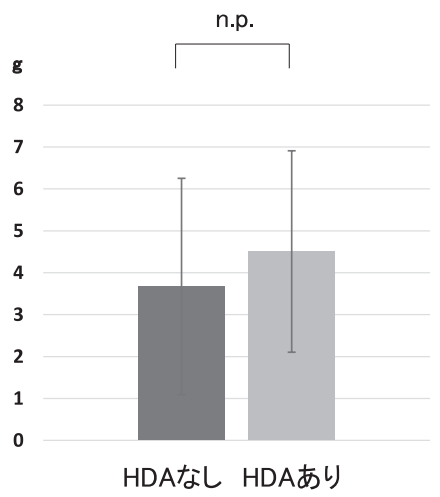

図 3 胃のHDA の有無と炭酸ランタンの服用状況

グラフは平均士標準偏差を示す。

a) HDA ありの群で服用期間が有意に長かった ( $t$ 検定).

b ）炭酸ランタンの総服用量は両群で有意差がなかった。

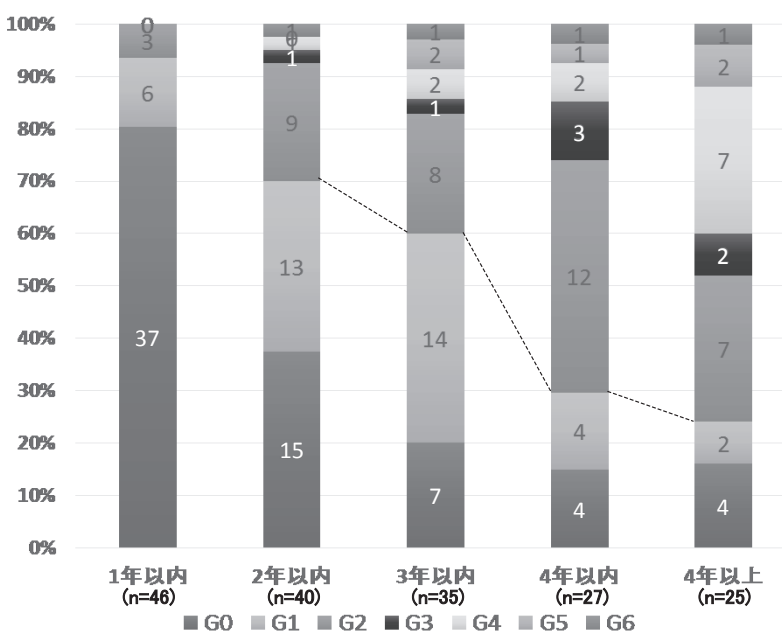

図 4 服用期間と胃の HDA 分類

服用期間が長いほど HDAの程度が有意に強かった $(\mathrm{p}<0.0001)$.

\section{2. 胃内視鏡検査を施行した 4 例の検討}

胃内視鏡検査を施行した 4 例は 60 歳台で透析歴は 10 年以上だった。吐き気, 食欲不振, 体重減少といっ
表 3 胃内視鏡検査を施行した症例

\begin{tabular}{c|c|c|c|c|r}
\hline \multirow{2}{*}{} & \multirow{2}{*}{ 年歯 } & \multirow{2}{*}{ 透析歴 } & \multirow{2}{*}{ CT 所見 } & \multicolumn{2}{|c}{ 炭酸ランタン } \\
\cline { 5 - 6 } & & & 服用期間 & 総服用量 \\
\hline 症例 1 & 67 & 15 年 3 か月 & $\mathrm{G} 6$ & 3 年 8 か月 & $1,868 \mathrm{~g}$ \\
症例 2 & 61 & 10 年 9 か月 & $\mathrm{G} 6$ & 3 年 4 か月 & $1,776 \mathrm{~g}$ \\
症例 3 & 65 & 18 年 8 か月 & $\mathrm{G} 5$ & 2 年 3 か月 & $608 \mathrm{~g}$ \\
症例 4 & 60 & 27 年 6 か月 & $\mathrm{G} 3$ & 4 年 4 か月 & $2,374 \mathrm{~g}$ \\
\hline
\end{tabular}

た消化器症状が出現したため, 胃内視鏡検査を行い, その後炭酸ランタンの服用を中止した. CT 所見は症 例 1 および症例 2 が $\mathrm{G} 6$ で, 症例 3 が $\mathrm{G} 5$, 症例 4 が G3 であった（表 3）.

内視鏡検査では症例 1 と症例 3 に胃粘膜のヒダに 沿って白色肥厚を認めた（図 $5 \mathrm{a}, \mathrm{c}$ ). 症例 2 はヒダ状 に白色肥厚を認め（図 5b), 症例 4 では環状の白色肥 厚を認めた（図 5d).

胃生検の病理組織所見として, 症例 3 の光学顕微鏡 写真と症例 4 の電子顕微鏡写真を示した (図 6, 図 7). 光学顕微鏡所見では胃粘膜には腺窩上皮がみられた。 


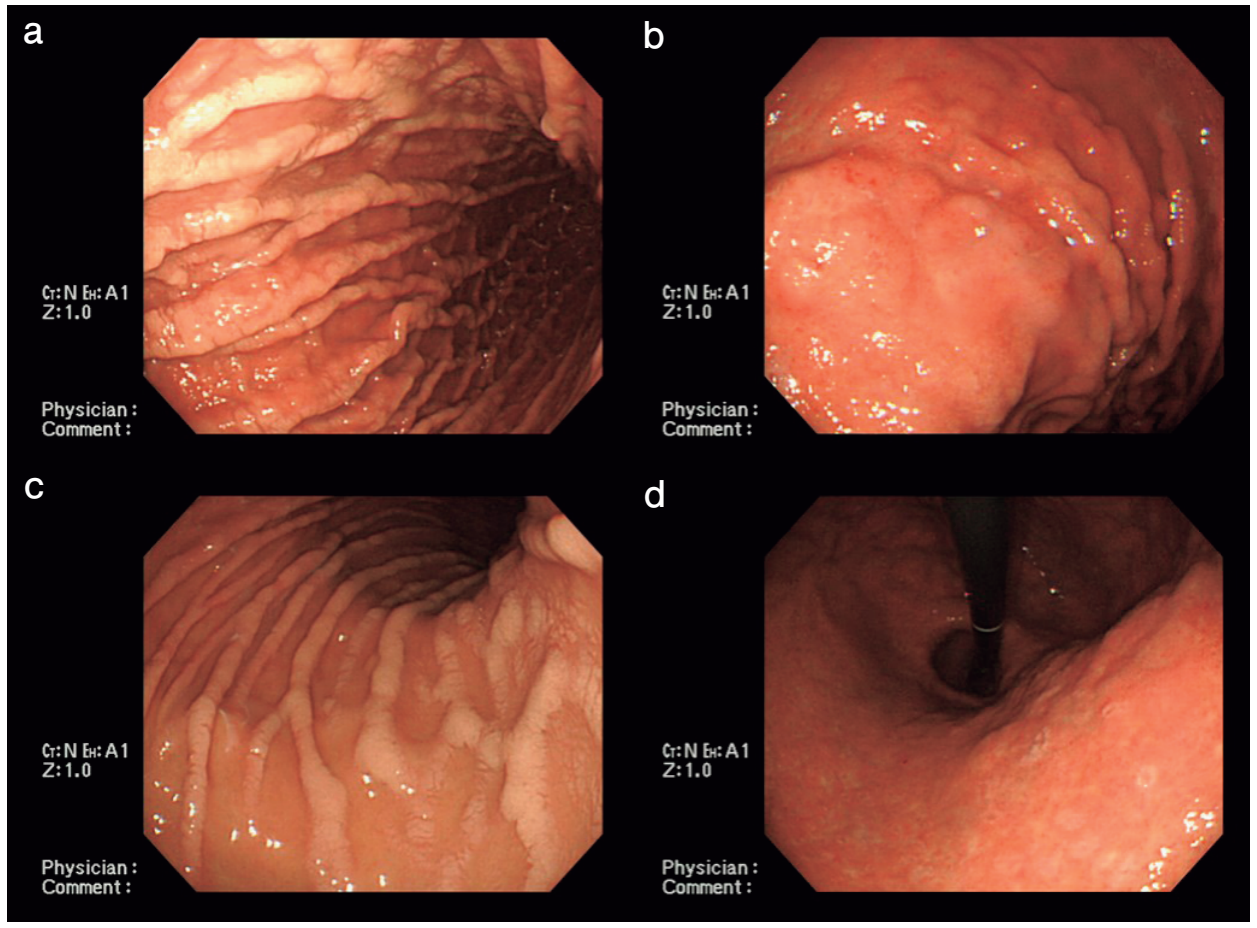

図 5 胃内視鏡検査所見

4 例（a. 症例 $1, \mathrm{~b}$. 症例 $2, \mathrm{c}$. 症例 3, d. 症例 4）とも胃粘膜の白色肥厚を認めた。

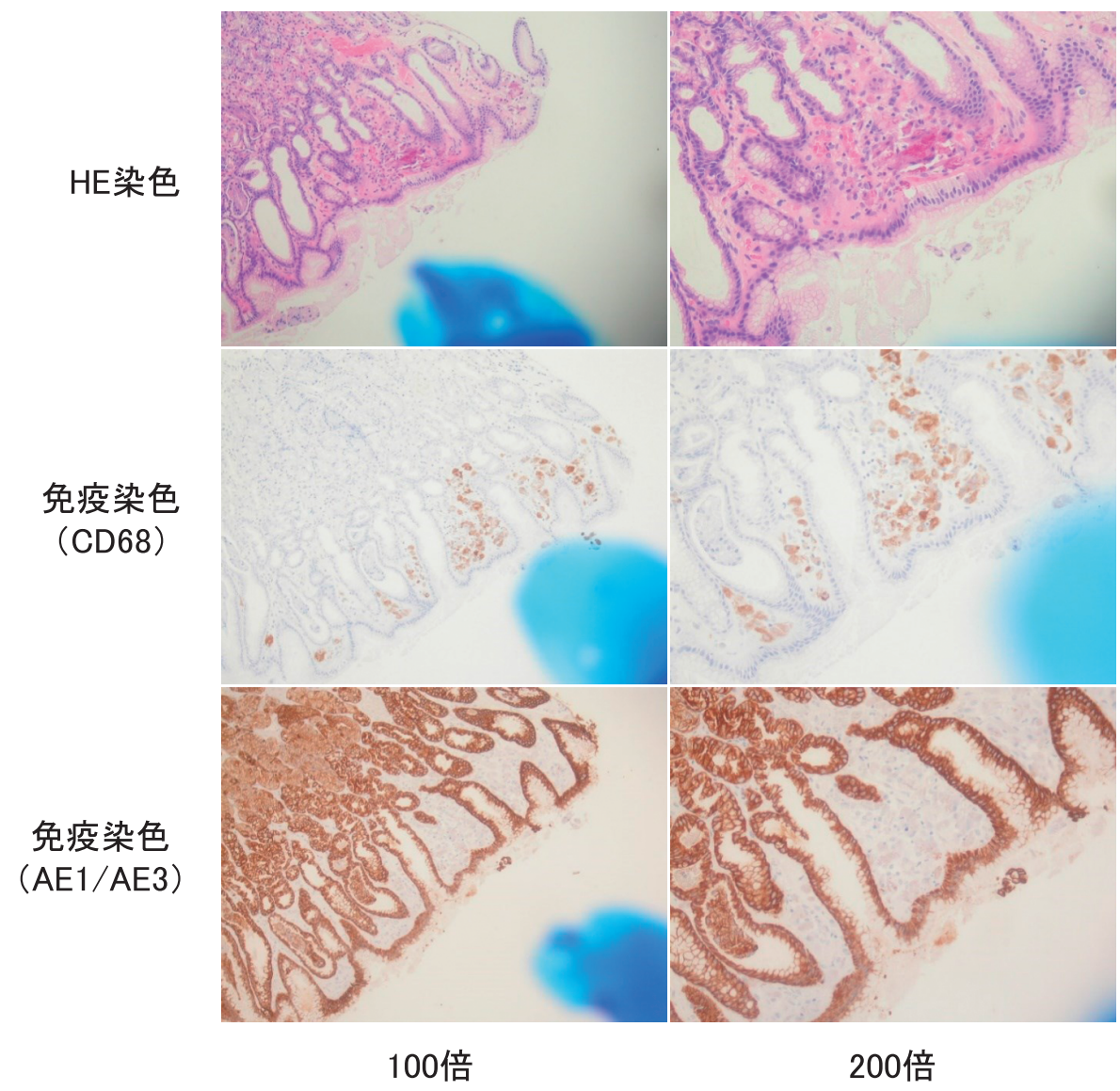

図 6 胃生検の光学顕微鏡所見

症例 3 の胃生検組織所見を示す。上段に HE 染色, 中段に免疫染色 (CD68), 下段に免疫 染色 (AE1/AE3) を示す. 粘膜固有層に好酸性から好塩基性の沈着物を認め, 連続切片 の免疫染色では CD68 陽性細胞が沈着物を貪食していた。AE1/AE3 陽性の上皮には沈着 物は認めなかった。 


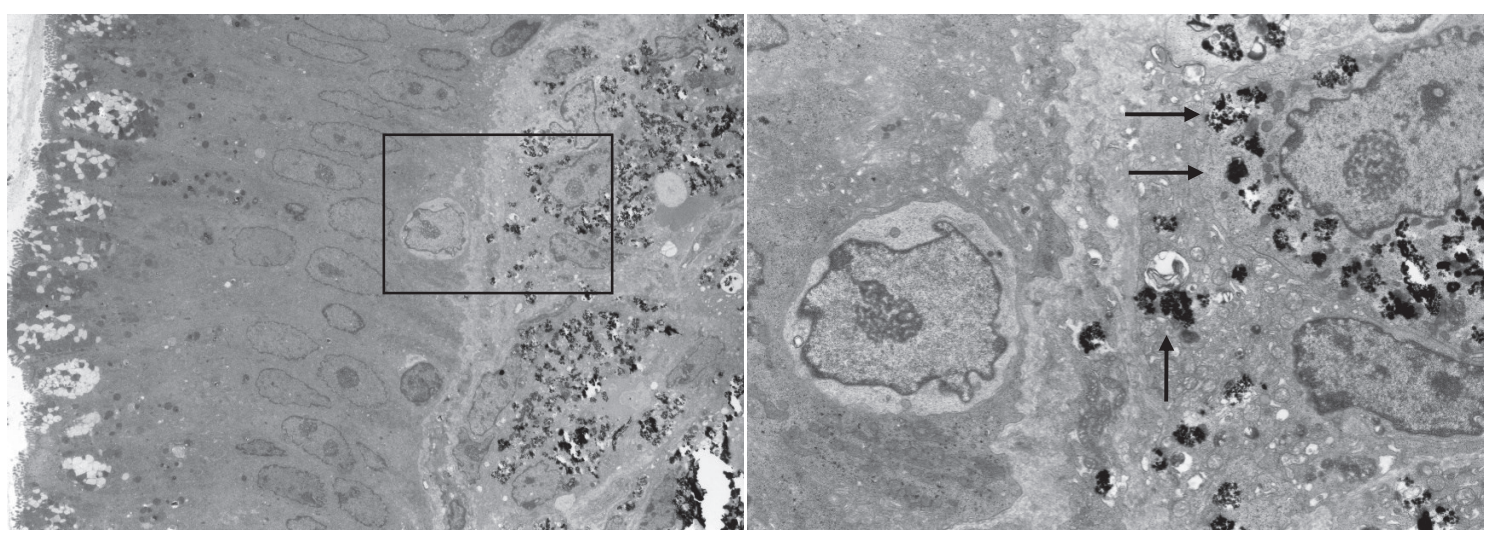

図 7 胃生検の電子顕微鏡所見

症例 4 の電子顕微鏡所見を示す (左 : 1,610 倍, 右 : 5,750 倍). 粘膜固有層に高電子密度の顆粒状, 針状, 不定形 の物質が多数沈着していた．強拡大ではマクロファージの細胞質内に free で存在していた $(\rightarrow)$.

\begin{tabular}{|c|c|c|}
\hline & & 定量値（ $\mu \mathrm{g} ）$ \\
\hline \multirow{2}{*}{ 症例 1} & \multirow{2}{*}{$\begin{array}{l}\text { sample } 1 \\
\text { sample } 2\end{array}$} & 4.8 \\
\hline & & 1.7 \\
\hline \multirow{2}{*}{ 症例 2} & \multirow{2}{*}{$\begin{array}{l}\text { sample } 1 \\
\text { sample } 2\end{array}$} & 9.6 \\
\hline & & 15 \\
\hline \multirow{2}{*}{ 症例 3} & \multirow{2}{*}{$\begin{array}{l}\text { sample } 1 \\
\text { sample } 2\end{array}$} & 14 \\
\hline & & 9.8 \\
\hline \multirow{2}{*}{ 症例 4} & \multirow{2}{*}{$\begin{array}{l}\text { sample } 1 \\
\text { sample } 2\end{array}$} & 22 \\
\hline & & 6.3 \\
\hline
\end{tabular}

定量值は試料全量あたりのランタン重

量を示す。（定量限界 0.0001）

胃粘膜固有層には好酸性から好塩基性ないし淡褐色調 物を貪食した組織球の浸潤を認めた，浮腫，血管増生， 充血，形質細胞，リンパ球の浸潤もみられた。胃底腺 の萎縮は軽度であった。連続切片の免疫染色では, $\mathrm{AE} 1 / \mathrm{AE} 3$ 陽性の上皮には沈着物は認めず, CD68 陽性 の組織球，多核巨細胞内に，沈着物がみられ，荟食像 であった（図 6)。電子顕微鏡所見では，胃粘膜上皮に 著変は認めなかったが, 粘膜固有層のマクロファージ の細胞質内に高電子密度の顆粒状，針状，不定形の物 質が多数沈着していた。この沈着物の多くは細胞質内 にfree で存在しており，部分的に沈着物が集合して大 きな塊を形成しており，一部に1枚の限界膜に囲まれ て認められた（図 7)。ほかの症例でも同様の病理組織 所見を認めた。

症例ごとに 2 個の胃生検組織からランタンの定量分 析を実施した。すべてのサンプルでランタンが検出さ れた（表 4)。C 型肝炎ウイルス陽性のサンプルがあっ たため, サンプルの重量および組織中濃度の測定はで きなかった。

\section{3. 炭酸ランタン中止後の推移}

胃内視鏡検查を施行後に炭酸ランタンを中止した 4 例のうち, 内服中止後に症例 1 と症例 3 に C T 検查を, また症例 3 に胃内視鏡検查を施行した。

症例 1 と症例 3 は, それぞれ投与期間 3 年 8 か月, 2 年 3 か月の時点で炭酸ランタンを中止した. 8 か月経 過後の CT 検査では胃の HDA は残存していた(図8). 症例 3 の胃内視鏡所見は炭酸ランタン服用中止後 8 か 月を経過しても，胃粘膜のヒダの白色肥厚を認めた (図 9)。生検による組織所見も前回と同様の所見を認 めた。

\section{IV. 考案}

炭酸ランタン服用中の血液透析患者の腹部 CT 所見 で，胃の HDA を高率に認めた，腸管内には HDA を 認めなかったので，胃粘膜表面に付着したランタンで はなく，胃粘膜に沈着したものと考えられた．胃内視 鏡検查を施行した症例では胃粘膜生検で粘膜固有層に 沈着物を認め, 胃粘膜組織の定量分析でランタンの存 在が確認された。これまで胃粘膜にランタンが沈着し たという報告はなく，本研究が最初の報告となった. 今回は腹部 CT の胃の HDA がきっかけになり, ラン タンが胃粘膜に沈着することを証明することができ た。これまで CT 検查で胃の HDA が問題にならな かった原因として考えられることは, 炭酸ランタンの 服用を継続したままで腹部 CT 検查を行うと, 胃や腸 管内に残存したランタンが HDA として認められ $れ^{11,12)}$, 胃の HDA が胃壁内なのか胃の中に残ったものなのか 区別が困難で，胃の腔内にあるとみなされてきた可能 性が考えられる。われわれの施設では炭酸ランタンを 休薬して腹部 $\mathrm{CT}$ 検查を行うために胃の HDA は埶内 
開始前

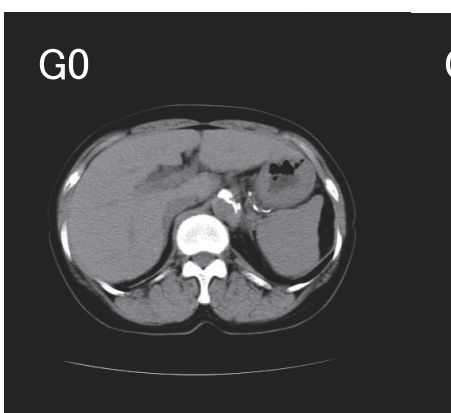

開始前
開始後6か月

G2

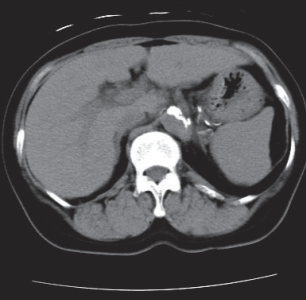

開始後5か月
中止前

G6

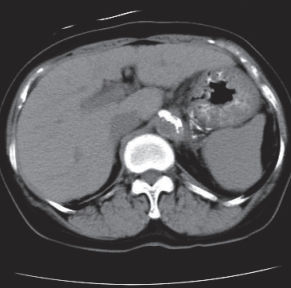

中止前
中止後8か月

G4

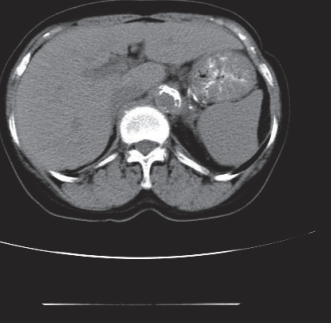

中止後8か月

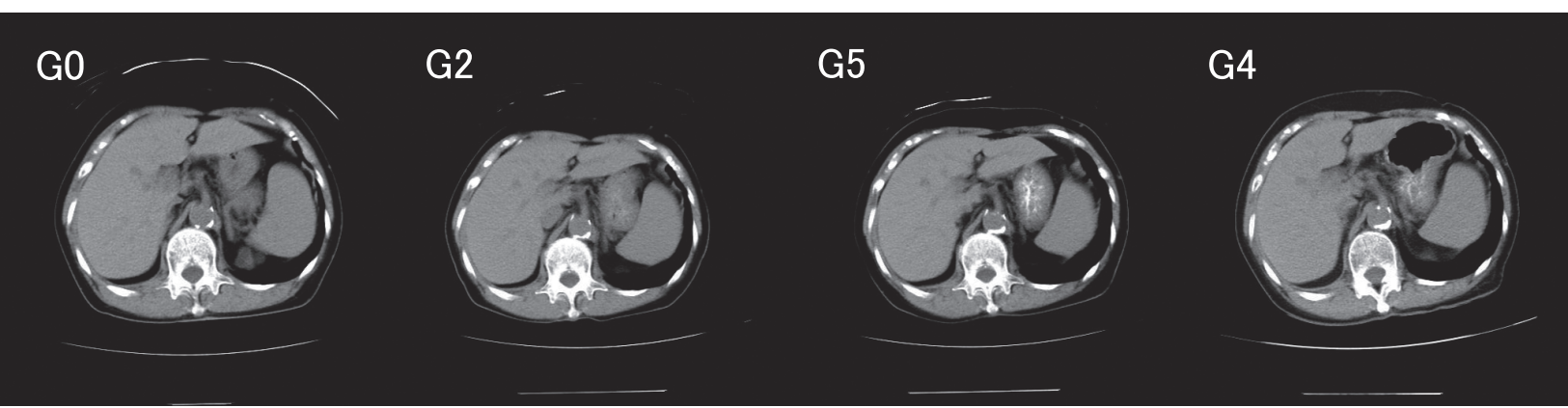

図 8 服薬中止前後の CT 所見の推移

症例 1 （上段：服用期間 3 年 8 か月）と症例 3 （下段：服用期間 2 年 3 か月）の CT 所見の推移を示す. 服薬中止後 8 か月を 経過しても胃の HDA は残存した。

中止前

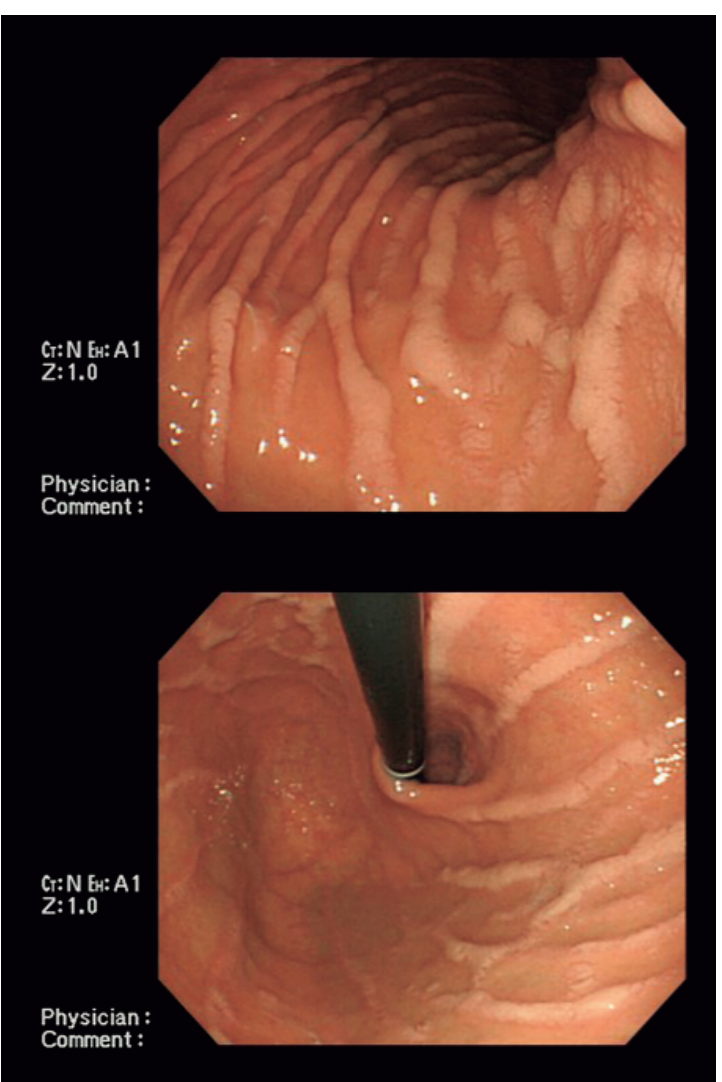

中止後8か月

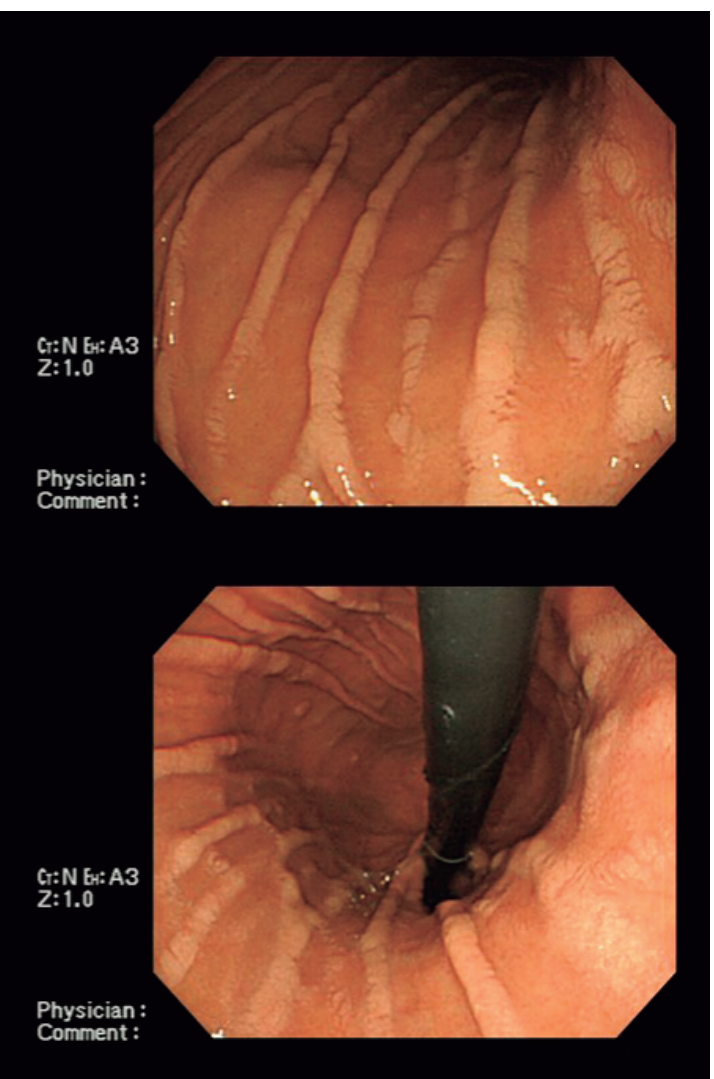

図 9 服薬中止前後の胃内視鏡所見の推移

症例 3 の胃内視鏡検查の推移を示す. 服薬中止後 8 か月を経過しても胃粘膜のヒダ状の白色肥厚が残存した。 
の炭酸ランタンではないことが診断できたものと考え られた。

炭酸ランタンの消化管からの吸収は細胞間隙を通し て行われ, 胃や腸管内の遊離ランタンイオン濃度と滞 在時間に依存する。腸管内の $\mathrm{pH}$ では炭酸ランタンは 溶解しないため腸管からの吸収は非常に低い，安静時 の胃の $\mathrm{pH}$ では炭酸ランタンは溶解するが, 食後の服 用では， $\mathrm{pH}$ が上昇してしまい，胃の表面積も小さい ため，胃からの吸収も制限される．このため消化管か らのランタンの吸収は非常に少ないと考元られてい る ${ }^{13)}$ ．ランタンが胃粘膜に沈着するためには遊離ラン タンイオン濃度と胃粘膜との接触時間が重要と考えら れるが，胃の中でランタンが遊離されれば，胃粘膜内 に侵入して沈着する可能性は十分に考えられる。 今回 の研究では腹部 CT 検査の胃の HDA は服用期間が長 かったものが有意に強かった、ランタンの沈着が HDA として描出されるにはある程度の沈着量が必要 と考えられるが, 沈着量を規定するのは総服用量より 服用期間が重要であると考えられた．また，胃内の $\mathrm{pH}$ は重要な要素と考えられるが, 今回は胃内 $\mathrm{pH}$ の検討 はできなかった．プロトンポンプ阻害薬と $\mathrm{H}_{2}$ ブロッ カーの服用と HDA の有無については関連がなかった が，今後前向き研究などで検討する必要があると考え られた。

今回われわれは胃粘膜固有層にランタンが沈着した 4 症例の病理組織を示した。ランタンが胃粘膜に沈着 してマクロファージの浸潤と領食がみられたことは, 異物を处理する反応と考元られ, 周囲に炎症を伴って いた、へリコバクター・ピロリによる慢性胃炎や胃潰 瘍の胃粘膜には多核白血球やマクロファージの浸潤が 顕著にみられると報告されているが14)，今回はへリコ バクター・ピロリ菌の感染については検討できなかっ た．今後検討する必要があると考えられた。

炭酸ランタン服用中止後の経過を検討した症例で は，中止後 8 か月を経過しても CT 所見や内視鏡所見 が残存していた。骨のランタン濃度は服薬中止後 2 年 経過してもあまり低下しなかったとの報告がある15).

ランタンが組織に沈着すると長期間にわたりその部位 に留まる可能性が考えられる。しかし，6年間の炭酸 ランタンの長期間の服用でも重篤な副作用はなかった と報告されている ${ }^{16,17)}$. 今回の研究では炭酸ランタン を服用すると胃粘膜にランタンが沈着することが証明 されたが，長期間の服用に抒いて沈着したランタンが 胃粘膜にどのような影響を与えるのか，今後も注意深 く検討する必要があると考えられた。

\section{結語}

炭酸ランタンの胃粘膜への沈着について検討した. 炭酸ランタン服用中の 70 例の血液透析患者では $60 \%$ (投与期間 3.45 年) に腹部単純 CT で胃に HDA が出現 し，服用期間と関連があった。胃内視鏡検査を施行し た 4 例の内視鏡所見は胃粘膜の白色肥厚が特徵的にみ られ，病理組織所見は胃粘膜固有層に沈着物やマクロ ファージの浸潤と貪食像を認め, 胃組織中にランタン 含有が確認された，炭酸ランタンは長期服用によって 胃粘膜固有層に沈着することが明らかとなった。この 現象が生体に与える影響について, さらに注意深く検 討する必要がある。

本論文の要旨は第 59 回日本透析医学会学術集会・総会 (2014 年 6 月) にて発表した.

開示すべき COI はなし.

謝辞 : 病理組織診断をお願いした戸田修二先生，瀬野尾 章先生に謹んで感謝いたします.

\section{文献}

1) D'Haese PC, Spasovski GB, Sikole A, et al. A multicenter study on the effects of lanthanum carbonate (Fosrenol) and calcium carbonate on renal bone disease in dialysis patients. Kidney Int 2003; 85 (Suppl): S73-8.

2) Damment SJ. Pharmacology of the phosphate binder, lanthanum carbonate. Ren Fail 2011; 33: 217-24.

3) Finn WF; SPD 405-307 Lanthanum Study Group. Lanthanum carbonate versus standard therapy for the treatment of hyperphosphatemia: safety and efficacy in chronic maintenance hemodialysis patients. Clin Nephrol 2006; 65: 191-202.

4) Pennick M, Dennis K, Damment SJ. Absolute bioavailability and disposition of lanthanum in healthy human subjects administered lanthanum carbonate. J Clin Pharmacol 2006; 46: 738-46.

5) Bervoets AR, Behets GJ, Schryvers D, et al. Hepatocellular transport and gastrointestinal absorption of lanthanum in chronic renal failure. Kidney Int 2009; 75: 389-98.

6) Lacour B, Lucas A, Auchère $D$, Ruellan N, de Serre Patey NM, Drüeke TB. Chronic renal failure is associated with increased tissue deposition of lanthanum after 28-day oral administration. Kidney Int 2005; 67: 1062-9.

7) Behets GJ, Verberckmoes SC, Oste L, et al. Localiza- 
tion of lanthanum in bone of chronic renal failure rats after oral dosing with lanthanum carbonate. Kidney Int 2005; 67: 1830-6.

8) Bronner F, Slepchenko BM, Pennick M, Damment SJ. A model of the kinetics of lanthanum in human bone, using data collected during the clinical development of the phosphate binder lanthanum carbonate. Clin Pharmacokinet 2008; 47: 543-52.

9) Behets GJ, Dams G, Vercauteren SR, et al. Does the phosphate binder lanthanum carbonate affect bone in rats with chronic renal failure? J Am Soc Nephrol 2004; 15: 2219-28.

10) Davis RL, Abraham JL. Lanthanum deposition in a dialysis patient. Nephrol Dial Transplant 2009; 24: 3247-50.

11) David S, Kirchhoff T, Haller H, Meier M. Heavy metal-rely on gut feelings: novel diagnostic approach to test drug compliance in patients with lanthanum intake. Nephrol Dial Transplant 2007; 22: 2091-2.

12) Pafcugová J, Horácková M, Hrasková M, Forejt J, Szabo M, Pádr R. Radio-opaque appearance of lanthanum carbonate in a patient with chronic renal failure. Nephrol Dial Transplant 2008; 23: 1776-7.

13) Damment SJ, Pennick M. Clinical pharmacokinetics of the phosphate binder lanthanum carbonate. Clin Pharmacokinet 2008; 47: 553-63.

14) Smith SM. Role of Toll-like receptors in Helicobacter pylori infection and immunity. World J Gastrointest Pathophysiol 2014; 5: 133-46.

15) Spasovski GB, Sikole A, Gelev S, et al. Evolution of bone and plasma concentration of lanthanum in dialysis patients before, during 1 year of treatment with lanthanum carbonate and after 2 years of follow-up. Nephrol Dial Transplant 2006; 21: 2217-24.

16) Hutchison AJ, Barnett ME, Krause RJ, Siami GA; Lanthanum Carbonate Study Group. Lanthanum carbonate treatment, for up to 6 years, is not associated with adverse effects on the liver in patients with chronic kidney disease Stage 5 receiving hemodialysis. Clin Nephrol 2009; 71: 286-95.

17) Persy VP, Behets GJ, De Broe ME, D’Haese PC. Management of hyperphosphatemia in patients with endstage renal disease: focus on lanthanum carbonate. Int J Nephrol Renovasc Dis 2009; 2: 1-8. 